\title{
Exploring the Development of Three Law-Based Competency Models for Practitioners
}

\author{
Montrece McNeill Ransom \\ Centers for Disease Control and Prevention, Atlanta, Georgia \\ Brianne Yassine \\ Cherokee Nation Assurance Contractor, Centers for Disease Control and Prevention, \\ Atlanta, Georgia
}

As public health promotion and protection become increasingly complex and integrated into various fields, public health law is emerging as an important tool for public health professionals. To ensure that public health professionals are effectively trained in public health law principles and theories, educators, trainers, and others who develop educational curricula should integrate public health law-related competencies into their training and workforce development efforts. This article provides three competency models developed by the Public Health Law Program at the Centers for Disease Control and Prevention: (a) the public health emergency law competency model, (b) the public health law competency model, and (c) the legal epidemiology competency model. These competency models provide a foundation upon which public health law curricula can be developed for governmental, nongovernmental, and academic public health practitioners. Such standardization of public health law curricula will ameliorate not only the training, but also selection and evaluation of public health practitioners, as well as better align public health training with national public health efforts.

Keywords: competencies, law, public health, public health law, law competencies, competency model

\section{Introduction}

Law is an important tool for protecting and promoting the health of the public. It has been critical in attaining public health goals and serves as the foundation for governmental public health practice. Public health law is a transdisciplinary field based in both legal practice and science, and public health laws are designed to have impact on environments and behavior (Burris, Ashe, Levin, Penn, \& Larkin, 2016). Law and policy strategies play an increasingly important role in addressing public health threats such as childhood obesity, healthcare-associated infections, and prescription drug overdoses. In the complex environment where policy and law impact public health programs and outcomes, it is critical for public health practitioners across specialties to be competent in the use of

Montrece McNeill Ransom also serves as contributing faculty with the School of Health Sciences, Walden University. Brianne Yassine is currently a doctoral student in the College of Education at the University of Georgia. The authors would like to express thanks to PHLP student interns Clarisa Medina (Summer 2016), Rose Meltzer (Summer 2017), and Monica George (Spring 2019) for their assistance with and contributions to this article. The authors declare no conflicts of interest. This document was coauthored by a Cherokee Nation Assurance contractor in the Public Health Law Program (PHLP) in the Center for State, Tribal, Local, and Territorial Support, Centers for Disease Control and Prevention (CDC). The findings and conclusions in this article are those of the authors and do not necessarily represent the official views of CDC. For further information, please contact PHLP at phlawprogram@cdc.gov.

Please address queries to: Montrece McNeill Ransom, Public Health Law Program, Center for State, Tribal, Local, and Territorial Support, Centers for Disease Control and Prevention. Email: mransom@cdc.gov 
public health law as an innovative tool to further the aims of their organizations (Bogaert et al., 2019; Sellers et al., 2015).

Modern public health practitioners want and need access to tools, training, and other opportunities that will help them achieve competencies in public health law and gain the skills needed to apply essential legal authorities (Miner, Childers, Alperin, Cioffi, \& Hunt, 2005). According to the 2015 Public Health Workforce Interest and Needs Survey conducted by the Association of State and Territorial Health Officials, the top two self-identified areas of training needs among public health professionals were how to influence law and policy development and how to understand the impacts of law and policy on population health (Sellers et al., 2015). Moreover, among the four elements of public health legal preparedness the Centers for Disease Control and Prevention (CDC) describes as integral for responding to emerging threats is a requirement to "establish and sustain the competencies of public health professionals to apply [public health] laws" (Goodman et al., 2006, para. 12).

In this article, we explore three competency models that delineate the desirable knowledge, skills, and abilities (KSAs) in law for the modern public health practitioner: (a) the public health emergency law competency model (PHELCM; Ransom, 2012), (b) the public health law competency model (PHLCM; Ransom, 2016), and (c) the legal epidemiology competency model (LECM; Ransom, Ramanathan, \& Yassine, 2018). We provide an overview of their impetus, development, and utility (Koo \& Miner, 2010). In the Background section, we provide background on the approach and methodology used to develop the three models. The Organization of the Public Health Law Competency Models section provides an overview of the organization of the three competency models. The Applications for the Public Health Law Competency Models section offers a discussion of how the models have been, and can be, used for practitioner training, performance management, and workforce development, as well as how the models align with national public health efforts by bolstering the 10 essential public health services and accreditation of public health law training programs. The conclusion offers perspectives on next steps and future opportunities to integrate public health law-related competencies into educational and other programming.

\section{Background}

\section{What Are Competencies?}

Competencies, in the context of public health, have been defined as "a complex combination of knowledge, skills, and abilities-frequently referred to as KSAs in the educational and instructional development and measurement literature-demonstrated by organization members that are critical to the effective and efficient functioning of the organization" (Calhoun, Rowney, Eng, \& Hoffman, 2005, p. 92). Building from the core competencies for public health professionals (Council on Linkages Between Academia and Public Health Practice [Council on Linkages], 2014), the public health law competencies provide a set of necessary skills in the use of law for public health practitioners. Competency in public health law can be defined as the level at which public health practitioners have the KSAs "to access and understand the relevant laws and to actually apply them to given health issues" (Moulton et al., 2003, p. 674). A competency model is a compilation of competency statements, organized into overarching domains, delineating the range of KSAs needed for satisfactory employee performance. Competency models can serve as building blocks to define work goals and accomplishments (Council on Linkages, 2014; Walsh et al., 2012). They may be used to guide educators in academic programs of public health and public health law and to guide on-thejob trainers in strategically developing the KSAs of staff members (Bruening, Coronado, Auld, Benenson, \& Simone, 2018; Patel, Powell, \& Woolard, 2008; Water Research Foundation, 2013). 
Competency-based education and training are not new to public health. In the realm of public health, competency-based training has been shown to improve individual performance, enhance communication and coordination across training programs and courses, and provide an impetus for trainer/faculty development, curricular reform, and leadership in educational and training innovation (Bruening et al., 2018; Calhoun, Ramiah, Weist, \& Shortell, 2008; National Commission for Health Education Credentialing, 2015). Scholars have noted that having access to action-oriented behavioral competencies to undergird training can significantly enhance learning and assessment outcomes. According to Koo and Miner (2010), "Competencies are critical for public transparency and accountability because they identify the specific skills to be gained by participating in an educational program, and subsequently provide the definable benchmarks for assessing the knowledge and skills gained" (p. 258). As on-the-job demand for public health law education increases (Allegrante, Moon, Auld, \& Gebbie, 2001; Evashwick, 2013; Resnick et al., 2019), it will be increasingly important for supervisors, agency leaders, and institutions offering public health law training to use public health law related competency models as tools to guide the development of curricula. Using competency models in this way will help establish learning objectives and training outcomes to build learner KSAs that have been validated by practitioners in public, academic, and private sectors of public health (see Public Health Law Academy at ChangeLab Solutions [https://www.changelabsolutions.org/good-governance/phla] and the Northwest Center for Public Health Practice's Public Health Law Training Database [https://www.nwcphp.org/training/phltraining-database\#b_start=0]).

\section{PHLP's Interest in Competency Modeling}

Law has been critical in attaining public health goals, serving as a foundation for governmental public health activities. Many of public health's greatest successes, including high childhood immunization rates, improved motor vehicle safety, safer workplaces, and reduced tooth decay, have relied heavily on law. Further, law is playing an increasingly important role in addressing emerging public health threats such as childhood obesity, healthcare-associated infections, motor vehicle injuries, and prescription drug overdoses.

Former CDC director Jeffrey Koplan established the Public Health Law Program in 2000 after consultations with CDC programs and extramural partners to lead the agency's public health law efforts. PHLP works to improve the health of the public by developing law-related tools and providing legal technical assistance to public health practitioners and policy makers in state, tribal, local, and territorial jurisdictions.

As early as 2001, scholars and practitioners began recognizing the need for law-based competencies for the public health workforce (Allegrante et al., 2001; Potter, Pistella, Fertman, \& Dato, 2000), and this is reflected in PHLP's mission to increase the use and understanding of law as a public health tool. In that year, the Center for Law and the Public's Health at Georgetown and Johns Hopkins universities, with support from CDC's Center for Preparedness and Response (CPR), led a project to characterize the necessary public health law-related competencies for public health professionals. The development of this competency model set the stage for the public health law competency modeling efforts discussed in this article. Many of the competency statements from this effort were included in the Competency Libraries, discussed in the Organization of the Public Health Law Competency Models section, which were instrumental to the development of PHLPs three public health law competency models. 


\section{Competency Modeling Approach and Methodology}

Each of the three competency models was completed over a 2-year period and in five distinct phases that closely mirror the competency model development process recommended by the U.S. Department of Labor (Competency Model Clearinghouse, 2019).

\section{Phase 1: Create a Competency Library}

A key first step in the competency modeling process is to gather information, including cataloging and organizing existing resources. In this phase, PHLP conducted literature reviews of medical, public health, and social science peer-reviewed journal articles, existing performance standards, competency statements, and competency models from varying public health professions. Each information-gathering process was undertaken with an eye toward identifying existing public health law-related competency statements and determining distinctions and commonalities.

Results of the reviews for each model were compiled into competency libraries. The final competency models are not limited to concepts from their respective competency library, but the libraries provided a common conceptual framework and provided a tool for categorizing initial ideas about which law-based KSAs would be applicable to practitioners in the field and should be included in the final model.

\section{Phase 2: Convene an Expert Review Panel}

During Phase 2 of the competency model development process, expert review workgroups (ERWs), each with 20-25 members, were convened. For the PHELCM, the ERW included primarily CPR staff. As PHLP refined its competency modeling approach, it expanded its ERWs to include multidisciplinary representatives of a comprehensive variety of areas within public health, public health law, legal research, training, and public health workforce development. For example, ERWs for the PHLCM and LECM included representatives from state and local health departments, federal government agencies, nongovernmental organizations, tribal-serving organizations, schools of law, and schools of public health.

The first task of each ERW was to review each competency statement included in the competency library. Members were then asked to prioritize the relative importance of each competency statement and delete any that were seen as unrelated to law-based KSAs, unimportant, or infrequently used in public health practice. The second task for each ERW member was to provide individual input on the competency model development process and offer comments and feedback on the draft models, as described below.

\section{Phase 3: Create Draft Models}

In Phase 3, ERW members and PHLP staff participated in an iterative process to develop initial drafts of each competency model for ERW review. PHLP staff used the statements from the competency library, as prioritized by ERW members, to identify overarching themes, or domains, under which specific competency statements of KSAs were organized. During monthly calls, the ERW offered comments about competency statements most critical to increasing the legal competency of the public health workforce across stages of career development. The information was used to prepare draft competency models for three tiers of professional practice: (a) entry-level or early career practitioners, (b) mid-tier practitioners in team lead or supervisory roles, and (c) professionals in senior manager or principal investigator roles.

The ERWs reviewed and edited the initial draft models to identify key components of each competency statement. The two guiding questions during this phase were (a) Do the statements accurately portray law-based KSAs needed to effectively practice public health, regardless of public health subject matter? (b) Are the statements clear and concise? PHLP crafted each draft model by 
organizing each compilation of competency statements into broader categories, or domains based on the KSA described. Tiers of professional practice (as described earlier) were added to represent similar KSAs at different career levels.

\section{Phase 4: Validate the Working Model}

The purpose of the validation step was to verify the accuracy and relevance of each working competency model's content (Society for Human Resource Management, n.d.). Although PHLP developed each model based on an extensive literature review and on the subject matter expertise offered by ERW members, content validation provided quantitative data about each model's content from a large sample of public health practitioners. Because the specific areas of public health law practice differed (public health emergency law, general public health law, and legal epidemiology research), validation for each model was conducted by different stakeholders and subject matter experts. Overall, though, the validation process for each model aimed to ensure that the competency model accurately reflected practical KSAs necessary for the specific area of public health law.

At the request of CPR leaders, PHLP focused the PHELCM validation process on ensuring that the competency model provided comprehensive integration into existing frameworks and practices in public health preparedness and response. To do this, PHLP staff conducted cross-walks comparing the PHELCM both to the Public Health Emergency Preparedness Capabilities and to existing public health emergency law training, tools, and resources (Northwest Center for Public Health Practice, 2014). This process provided CPR and the field with information as to how the PHELCM fits within the landscape of current frameworks in preparedness and response, and the ways the PHELCM adds value to inform planning and decision-making of quality legal preparedness training and education programming.

To validate the PHLCM, PHLP worked with public health training experts at ChangeLab Solutions and the Northwest Center for Public Health Practice to evaluate the extent to which application of the model assisted in the development and delivery of public health law-related curriculum, and whether participants self-reported an increase in competency after completing the competency-based training. The Northwest Center for Public Health Practice (2014) evaluated two in-person trainings-Public Health Law 101 for Local Health Officials and Legal and Policy Approaches to Reducing Prescription Drug Overdose-and interviewed curriculum developers and content experts. Three recommendations from the validation process (i.e., use plain language, provide guidance on use, and track ongoing use to ensure all competencies are being applied) were incorporated in the final version of the PHLCM.

The Public Health Foundation guided the LECM validation process and provided feedback on the competency model development process and the framework for the draft model. In May 2017, the Public Health Foundation hosted a virtual town hall attended by more than 125 public health practitioners (Ransom et al., 2016). During and after this online meeting, participants were offered opportunities to provide edits, suggestions, and comments on the draft LECM. This feedback is reflected in the version of the LECM presented in Appendix A.

\section{Phase 5: Refine and Finalize the Model}

The results of the validation phase demonstrated that the competency statements in each model provide a good framework for improving both the relevance of public health law training opportunities and the competency of the public health workforce. One key recommendation from the validation process was to ensure that each competency statement was succinct and written so that it could be used by the broader public health practice community. To that end, in the refinement phase, each model was reviewed closely to ensure plain language principles had been applied. 
The final vetting of each competency model was conducted by reviewers from partner organizations, including the Association of State and Territorial Health Officials, the American Public Health Association, National Conference of State Legislatures, Association of Schools and Programs in Public Health, National Association of County and City Health Officials, ChangeLab Solutions, and the Network for Public Health Law. Before moving forward with dissemination, PHLP solicited review from leaders, and potential end users, within these critical partner organizations, and feedback confirmed the accuracy and usefulness of the final versions of the competency models and supported the need for these tools in the field.

\section{The Public Health Emergency Law Competency Model Version 1.0}

The catalyst for PHLP's recent competency modeling work was a request from CDC's CPR in 2012. Given the significance of public health law to effective public health emergency preparednessrecognizing this critical gap in existing emergency preparedness standards and capabilities-CPR asked PHLP to develop a set of competencies in public health emergency law for public health professionals in leadership, management, or supervisory roles who are involved with emergency preparedness and response. As a result, PHLP, in collaboration with the Association of Schools and Programs in Public Health, developed the PHELCM in 2013 (see Appendix A). The PHELCM presents a core set of law-specific KSAs necessary for public health professionals to engage in effective emergency preparedness and response.

\section{The Public Health Law Competency Model}

After creating, disseminating, and using the PHELCM in the development of training materials, PHLP began developing a model focused on general legal principles that impact day-to-day public health practice. PHLP held informal conversations with stakeholders representing state, tribal, local, and territorial public health agencies, schools of public health and law, federal public health agencies, and partners across the health system about the utility of a general public health law competency model. Prior to this, PHLP also conducted a needs assessment of a sample of 351 subscribers to CDC's Public Health Law News. One of the primary goals of this needs assessment was to identify gaps in legal knowledge and training needs of public health practitioners. Both the informal conversations and the needs assessment results highlighted a common need for training in legal principles and concepts, specifically the constitutional foundations for public health practice. The majority of respondents to the needs assessment reported low competency in public health law KSAs and indicated a need for both legal training and legal technical assistance. In particular, respondents noted interest in the fundamentals of public health law, including the legal basis for public health practice and scope of authority, the legal foundations for public health surveillance and investigations, and the role of law in the prevention and control of both chronic and infectious disease.

These data demonstrated that public health practitioners desire competency-based training in law and could benefit from an easy-to-use competency model that would clarify the desired law-related KSAs expected public health practitioners. To this end, the PHLCM was finalized and disseminated in the summer of 2016 (see Appendix B).

\section{The Legal Epidemiology Competency Model}

The third and most recently developed model is the LECM (see Appendix C). The LECM was developed in response to a need for guidelines for the minimum competencies in legal epidemiologythe scientific study of law as a factor in the cause, distribution, and prevention of disease and injury (Burris et al., 2016). Released in 2017, the LECM has the promise to (a) provide a common language to describe the critical skills and knowledge of practitioners engaged in legal epidemiology research; 
(b) drive the development of legal epidemiology-focused curricula, scholarly support, and additions to the literature; and (c) guide the development of products related to public health law research and training under federal capacity-building cooperative agreements and similar funding opportunities.

\section{Organization of the Public Health Law Competency Models}

At the request of CDC's CPR, the PHELCM was developed to target mid-tier public health practitioners. However, in both the PHLCM and the LECM, competencies are delineated across three tiers of career development in public health practice. The tiers build on each other, describe KSAs necessary at progressive stages of careers, and align with the three distinct stages of public health career development as defined by the Public Health Foundation's Council on Linkages (2014). Tier 1 is designed to capture competencies applicable to entry level practitioners with 1-3 years of experience. Tier 2 captures competencies applicable to mid-tier practitioners in leadership, management, or supervisory roles. Tier 3 captures competencies applicable to professionals at a senior management or principal investigator level who are responsible for setting strategy, overseeing programs and operations, and overseeing staff.

\section{Overarching Domains and Competency Statements}

Each of the PHLP-developed competency models has several overarching domains used to organize the accompanying competency statements. The competency statements under each domain are intended to be a set of broadly accepted guidelines for minimum competencies in law needed by public health practitioners in governmental, non-governmental, and academic environments. The competency statements in the models do not encompass every law-based KSA needed in public health practice, nor do they represent all of the law-based KSAs necessary for every job. Instead, the statements in each of the three models discussed in this article are designed to capture a broad set of skills and knowledge of law and legal frameworks that encompass the practice of public health. Ideally, the competency models can be customized for individual and organizational needs.

As depicted in Appendix A, the PHELCM consists of nine competency statements organized within three domains of public health emergency preparedness and response, including (a) systems preparedness and response, (b) management and protection of property and supplies, and (c) management and protection of persons. At the request of CDC's CPR, and unlike the PHLCM and the LECM, the PHELCM is limited to competency statements for mid-tier public health professionals and does not include behavioral statements across the three tiers of career progression. Domain 1 of the PHELCM concentrates on systems preparedness and response and covers competencies related to understanding and using legal authority during a public health emergency, the impact of an emergency declaration, and when to consult legal counsel. The domain dedicated to the management and protection of property and supplies, Domain 2, focuses on knowledge and skills related to implementing legal tools like injunctions, closing orders, searches and seizures, destruction of property, and the dispensation of medical supplies. Domain 3 offers competency statements that address the management and protection of persons, including the use of social distancing and liability related issues. Each of these domains aligns with the PHLP-developed course, Public Health Emergency Law, which has been delivered in more than 45 jurisdictions (Sunshine \& Ransom, 2016) and has been recently released for free online at https://www.cdc.gov/phlp/publications/topic/trainings/ph-emergencylaw.html.

The PHLCM, shown in Appendix B, includes two domains-law as the foundation of governmental public health practice (Table B1) and law as a tool to advance the public's health (Table B2) —and six competency statements. It is intended to provide a framework for the KSAs expected of entry-level, supervisory, and executive-level public health practitioners working in state, tribal, local, and territorial health departments. Domain 1 offers competency statements that support the 
understanding of foundational legal principles and concepts associated with the practice of public health law, including equal protection, federalism, police powers, and tribal sovereignty. Domain 2 focuses the competencies needed to understand and use law as an interventional tool. The competency statements in this domain address the need for practitioners to be able to identify and use law based tools and enforcement procedures in the day-to-day practice of public health.

The LECM, depicted in Appendix C, is organized into three major domains: general legal epidemiology competencies, legal mapping, and advanced legal epidemiology methods. Domain 1 focuses on cross-cutting knowledge and includes statements related to basic research and epidemiology skills needed to conduct and translate legal epidemiology studies. Domain 2 addresses competencies needed to conduct legal mapping studies, including those related to identifying the need for and designing policy surveillance projects. Domain 3 focuses on advanced legal epidemiology methods and includes statements related to designing projects that study potential associations between health and law.

\section{Applications for the Public Health Law Competency Models}

\section{Uses for Public Health Law Competency Models}

The models are designed to reflect the practice of public health, and yet are not intended to limit that practice. Formal evaluation of the use of each competency model by practitioners in the field is forthcoming. However, each of the public health law competency models has been disseminated to wide audience through PHLP's Public Health Law News and PHLP's work with partners including the Association for Schools and Programs of Public Health, the American Public Health Association, and the Society for Public Health Education. Initial reactions have been favorable from public health practitioners, trainers, and academic partners. In providing informal feedback on the PHLCM, one user noted, "From a big picture perspective, this helps us have a more cohesive workforce and more standardized services around the country."

Because strategic skill-building occurs on the job (Koo \& Miner, 2010; Sellers et al., 2019), the goal of developing these competency models is for public health agencies, and partners across the system, to use the public health law competency models to help address complex public health problems. The competency statements included in each model can be useful for crafting position descriptions and providing guidance for organizational performance appraisals or personal benchmarks. They can be used by agencies to develop effective and measurable training programs and to identify other quality educational opportunities. Ideally, the models will be used to identify skill and competency gaps more efficiently; to incorporate elements of public health law into existing and future public health law curricula; to recruit, select, and evaluate performance of public health practitioners more effectively; and to contribute to career ladders and employee development and training plans.

PHLP anticipates that faculty and students across a broad range of institutions-including schools and programs in public health, law, international relations/affairs, business schools, schools of social work, schools of information, and other health professions' schools, such as medicine and nursingwill find value in these competency models. According to an academic partner, "As someone invested in ensuring that legal concepts are accessible beyond the legal community, I think you have succeeded in using language and concepts that meet that goal."

Ideally, the competency models will be the standard used by practitioners to ensure that public health law research and educational programming-including academic curricula and practitioner trainings-are competency-based. For instance, under a cooperative agreement managed by CDC's Center for State, Tribal, Local, and Territorial Support, ChangeLab Solutions has developed a series of competency-based trainings in general public health law and a series of legal epidemiology 
trainings using the PHLCM and the LECM as guides. These free, on-demand trainings are available at https://www.changelabsolutions.org/good-governance/phla.

CDC's Public Health Emergency Law 4.0 course was developed based on the PHELCM and is divided into three legal preparedness units that align directly with the three domains of the model: (a) Systems Preparedness and Response, (b) Management and Protection of Responders and the Public, and (c) Protection and Use of Property and Supplies. To date, PHLP staff have traveled to more than 17 states and delivered 20 Public Health Emergency Law 4.0 trainings to nearly 1,000 public health practitioners (Sunshine \& Ransom, 2016). Before each course starts, attendees are given a 10-question pretest to assess their competence in legal preparedness principles and frameworks. At the end of the course, attendees answer the same 10 questions again. Across the 20 Public Health Emergency Law 4.0 trainings given between August 2015 and August 2018, participants demonstrated a $22 \%$ average increase in knowledge, based on pre-and posttest scores. These improvements illustrate just one example of the value of competency-based training.

\section{Application to National Public Health Efforts}

Not only are these competency models important tools to help practitioners improve their knowledge and skills, but linking them — and the benchmarks they set—-to national initiatives can also be beneficial.

\section{The 10 Essential Public Health Services}

The public health system performs the three functions of assessment, policy development, and assurance by delivering 10 Essential Public Health Services to constituents (see Appendix D; CDC, 2018). All three public health law competency models can help state, tribal, local, and territorial public health agencies provide the essential services that are concerned with developing policies and plans (Service 5); enforcing laws and regulations that protect health and ensure safety (Service 6); ensuring a competent workforce (Service 8); evaluating the effectiveness, accessibility, and quality of personal and population based health services (Service 9); and researching for new insights and innovative solutions to health problems (Service 10). At the core of the 10 Essential Public Health Services model lies research, including legal research, because it forms the basis for each function (CDC, 2018). Public health practitioners who become proficient in the public health law competencies will be equipped to analyze problems that need a policy or legal solution and will have the necessary skills to propose solutions grounded in law. With these skills, practitioners working in public health agencies will be able to help their agencies demonstrate staff competence for using law as a tool to advance public health.

\section{Public Health Accreditation}

Understanding law and policy is also critical to the nation's efforts to support public health department accreditation. "The mission of the voluntary national accreditation program is to improve and protect the health of the public by advancing and ultimately transforming the quality and performance of the nation's state, Tribal, local, and territorial public health departments" (Public Health Accreditation Board, 2019, para. 1). The Public Health Accreditation Board's process outlines standards that are grouped into 12 domains that define the expectations for health departments seeking accreditation. The PHLCM can advance accreditation goals as agencies seeking accreditation consider the standards under several domains. For example, Domain 6 expressly focuses on understanding and enforcing public health laws. Standard 6.2 specifically requires that health departments seeking accreditation "educate individuals and organizations on the meaning, purpose, and benefit of public health laws, and how to comply" (Public Health Accreditation Board, 2019). Other relevant domains include standards and measures such as policy development and 
emergency response operations (Domain 5), the use of core and discipline-specific competencies in workforce development efforts (Domain 8), and knowledge of the authority to provide public health services (Domain 12). Practitioners who lead their jurisdiction's accreditation efforts should find the PHLCM useful for ensuring that public health law-related training and educational efforts are competency based.

\section{Conclusion}

Public health practitioners, even those without a law degree, should be competent in basic principles of public health law and legal research. Laws shape and impact the social and structural determinants of health by changing the context in which we live, work, and play (Emery \& Crump, 2006; Frieden, 2010). The field of public health law spans and complements every public health discipline and is constantly evolving to analyze and address emerging population health concerns. Public health law can deliver a public health intervention to hundreds of thousands of individuals with the stroke of a pen (Burris et al., 2016).

PHLP's competency model development process is a comprehensive, community of practice and expert panel effort with ongoing field-wide dissemination and calls for input by interested parties, including public health faculty, partners, practitioners, and students. The subject matter experts on each ERW represented academia, the private sector, and government agencies across states, tribes, localities, and territories to accurately capture the work being done in the field.

Each model aims to define the core competencies in law needed for effective public health practice. However, the models will not remain static; each model is a living document that describes the competencies in law needed by present-day public health practitioners. Competency model development is an iterative process, and each model will have to be regularly updated through continued dialogue regarding the use of the competencies, input on the currency and relevancy of the model, and ongoing changes in the field of public health and public health law. Future directions for these models include further refinement in line with new thinking and future challenges to the field. Input, evaluation, and feedback from end users is critical to ensuring that each model becomes a valuable tool that meets the needs of an evolving public health workforce.

For the modern public health practitioner, public health law KSAs are necessary for advancing community health goals and are critical to the future success of the U.S. public health system. Understanding and using the law-based competency models described in this article is key to ensuring that current and future generations of the public health workforce are competent in the use of law and legal mechanisms to address new and emerging public health issues. Public health practitioners, particularly, training and workforce development professionals, academics, and other relevant partners, have important roles in this future success, and should find these models helpful.

\section{References}

Allegrante, J. P., Moon, R. W., Auld, M. E., \& Gebbie, K. M. (2001). Continuing-education needs of the currently employed public health education workforce. American Journal of Public Health, 91, 1230-1234.

Bogaert, K., Castrucci, B. C., Gould, E., Rider, N., Whang, C., \& Corcoran, E. (2019). Top training needs of the governmental public health workforce. Journal of Public Health Management and Practice, 25, S134-S144. doi:10.1097/phh.0000000000000936

Bruening, R. A., Coronado, F., Auld, M. E., Benenson, G., \& Simone, P. M. (2018). Health education workforce: Opportunities and challenges. Preventing Chronic Disease, 15, E89. doi:10.5888/pcd15.180045 
Burris, S., Ashe, M., Levin, D., Penn, M., \& Larkin, M. (2016). A transdisciplinary approach to public health law: The emerging practice of legal epidemiology. Annual Review of Public Health, 37, 135-148. doi:10.1146/annurev-publhealth-032315-021841

Calhoun, J. G., Ramiah, K., Weist, E. M., \& Shortell, S. M. (2008). Development of a core competency model for the master of public health degree. American Journal of Public Health, 98, 15981607. doi:10.2105/ajph.2007.117978

Calhoun, J. G., Rowney, R., Eng, E., \& Hoffman, Y. (2005). Competency mapping and analysis for public health preparedness training initiatives. Public Health Reports, 120, 91-99. doi:10.1177/00333549051200S117

Centers for Disease Control and Prevention (CDC). (2018). The public health system and the 10 essential public health services. Retrieved from https://www.cdc.gov/publichealthgateway/publichealthservices/essentialhealthservices.html

Competency Model Clearinghouse. (2019). A process to develop competency models. Retrieved from https://www.careeronestop.org/CompetencyModel/GetStarted/model-collaborativeprocess.aspx

Council on Linkages Between Academia and Public Health Practice (Council on Linkages). (2014). Core competencies for public health professionals. Retrieved from http://www.phf.org/resourcestools/Documents/Core_Competencies_for_Public_Health_Profess ionals_2014June.pdf

Emery, J., \& Crump, C. (2006). Public health solutions through changes in policies, systems, and the built environment: Specialized competencies for the public health workforce directors of health promotion and education. Retrieved from http://dhss.alaska.gov/dph/Chronic/Documents/01External/hpec_comps_phase_final.pdf

Evashwick, C. J. (2013). Educating the public health workforce. Frontiers in Public Health, 1, 20. doi:10.3389/fpubh.2013.00020

Frieden, T. R. (2010). A framework for public health action: the health impact pyramid. American Journal of Public Health, 100, 590-595. doi:10.2105/AJPH.2009.185652

Goodman, R., Moulton, A., Matthews, G., Shaw, F., Kocher, P., Mensah, G., . . Besser, R. (2006). Law and public health at CDC. Morbidity and Mortality Weekly Report, 55, 29-33.

Koo, D., \& Miner, K. (2010). Outcome-based workforce development and education in public health. Annual Review of Public Health, 31, 253-269. doi:10.1146/annurev.publhealth.012809.103705

Miner, K. R., Childers, W. K., Alperin, M., Cioffi, J., \& Hunt, N. (2005). The MACH model: From competencies to instruction and performance of the public health workforce. Public Health Reports, 120,9-15. doi:10.1177/00333549051200S104

Moulton, A. D., Gottfried, R. N., Goodman, R. A., Murphy, A. M., \& Rawson, R. D. (2003). What is Public Health Legal Preparedness? The Journal of Law, Medicine \& Ethics, 31, 672-683. doi:10.1111/j.1748-720X.2003.tb00134.x

National Commission for Health Education Credentialing. (2015). Areas of responsibility, competencies, and sub-competencies for health education specialists. Retrieved from https://www.speakcdn.com/assets/2251/hespa_competencies_and_sub-competencies.pdf

Northwest Center for Public Health Practice. (2014). Competencies: A roadmap for professional development. Retrieved from http://www.nwcphp.org/communications/news/competenciesroadmap-for-professional-development 
Patel, A. S., Powell, T. A., \& Woolard, C. D. (2008). Assessment of applied epidemiology competencies among the Virginia Department of Health workforce. Public Health Reports, 123, 119-127. doi:10.1177/00333549081230S115

Potter, M. A., Pistella, C. L., Fertman, C. I., \& Dato, V. M. (2000). Needs assessment and a model agenda for training the public health workforce. American Journal of Public Health, 90, $1294-1296$.

Public Health Accreditation Board. (2019). What is accreditation? Retrieved from https://www.phaboard.org/accreditation-overview/what-is-accreditation/

Ransom, M. M. (Ed.). (2012). The public health emergency law competency model: Version 1.0. Retrieved from: https://www.cdc.gov/phlp/docs/compentency-modelv1.pdf

Ransom, M. M. (Ed.). (2016). Public health law competency model: Version 1.0. Retrieved from https://www.cdc.gov/phlp/docs/phlcm-v1.pdf

Ransom, M. M., Ramanathan, T., \& Baker-White, A. (2016). Virtual town hall meeting: Exploring competencies for the emerging field of legal epidemiology. Retrieved from http://www.phf.org/events/Pages/Virtual_Town_Hall_Meeting_Legal_Epidemiology_Compete ncy_Model.aspx

Ransom, M. M., Ramanathan, T., \& Yassine, B. (Eds.). (2018). The legal epidemiology competency model: Version 1.0. Retrieved from https://www.cdc.gov/phlp/publications/topic/resources/legalepimodel/index.html

Resnick, B. A., Morlock, L., Diener-West, M., Stuart, E. A., Spencer, M., \& Sharfstein, J. M. (2019). PH WINS and the future of public health education. Journal of Public Health Management and Practice, 25, S10-S12. doi:10.1097/phh.0000000000000955

Sellers, K., Leider, J. P., Gould, E., Castrucci, B. C., Beck, A., Bogaert, K., . . Erwin, P. C. (2019). The state of the us governmental public health workforce, 2014-2017. American Journal of Public Health, 109, 674-680. doi:10.2105/ajph.2019.305011

Sellers, K., Leider, J. P., Harper, E., Castrucci, B. C., Bharthapudi, K., Liss-Levinson, R., . . Hunter, E. L. (2015). The public health workforce interests and needs survey: The first national survey of state health agency employees. Journal of Public Health Management and Practice, 21, S13-27. doi:10.1097/phh.0000000000000331

Society for Human Resource Management. (n.d.). Content validation study of the SHRM competency model. Retrieved from https://www.shrm.org/LearningAndCareer/competencymodel/Documents/14-0705\%20Content\%20Validation\%20Study\%203.pdf

Sunshine, G., \& Ransom, M. M. (2016). The 2015 legal preparedness roadshow: A summer road trip to teach government personnel the basics of public health emergency law. ABA Health eSource, 12,9 .

Walsh, L., Subbarao, I., Gebbie, K., Schor, K. W., Lyznicki, J., Strauss-Riggs, K., . . James, J. J. (2012). Core competencies for disaster medicine and public health. Disaster Medicine and Public Health Preparedness, 6, 44-52. doi:10.1001/dmp.2012.4

Water Research Foundation. (2013). Competency model development and application to meet water utility workforce needs. Retrieved from https://www.waterrf.org/research/projects/competency-model-development-and-applicationmeet-water-utility-workforce-needs 


\section{Appendix A \\ Public Health Emergency Law Competency Model}

\section{Domain 1: Systems Preparedness and Response}

-1.1: Act within the scope of federal, state, tribal, and local statutory and regulatory authority during emergency situations, and through state and/or federal declarations of emergency

-1.2: Communicate legal authority and procedures to emergency response partners, such as other public health agencies, other health agencies, and other government agencies during planning, drills, and actual emergencies

-1.3: Identify limits to legal knowledge, skill, and authority and key system resources, including legal advisors, for referring matters that exceed those limits

-1.4: Integrate legal information into the exercise of professional public health judgment within the larger public health response
Domain 2:

Management

and Protection

of Property

and Supplies
-2.1: Implement the use of relevant legal information, tools, procedures, and remedies including injunctions, closing orders, and abatement orders

-2.2: Identify how and under what circumstances legal searches, seizures, and destruction of property and materiel can take place for public health purposes

-2.3: Describe the legal authorities related to the distribution and dispensation of medical supplies and the effect of a state and/or federal emergency or public health declaration on those authorities

\section{Domain 3:}

Management and Protection of Persons
-3.1: Implement the use of relevant legal information, tools, procedures, and remedies related to social distancing including evacuation, quarantine and isolation orders, closure of public places, curfews

-3.2: Recognize the sources of potential civil and criminal liability of public health personnel and consider due process issues before taking legal action 


\section{Appendix B}

\section{Public Health Law Competency Model Version 1.0: Domains, Competencies, Key Behaviors, and Training Topics}

Table B1. Domain 1: Law as the Foundation of Governmental Public Health Practice

\begin{tabular}{|c|c|c|c|}
\hline Competency Statement & $\begin{array}{c}\text { Tier } 1 \\
\text { Entry Level }\end{array}$ & $\begin{array}{c}\text { Tier } 2 \\
\text { Supervisory }\end{array}$ & $\begin{array}{c}\text { Tier } 3 \\
\text { Executive }\end{array}$ \\
\hline $\begin{array}{l}\text { 1.1 } 1^{\text {a: }} \text { Define basic constitutional concepts } \\
\text { and legal principles framing the practice } \\
\text { of public health across relevant } \\
\text { jurisdictions }\end{array}$ & $\begin{array}{l}\text { Describe the public health laws } \\
\text { and regulations governing public } \\
\text { health program and related } \\
\text { practices }\end{array}$ & $\begin{array}{l}\text { Manage public health programs and } \\
\text { practices in a way that is } \\
\text { consistent with public health laws } \\
\text { and regulations }\end{array}$ & $\begin{array}{l}\text { Ensure public health programs } \\
\text { and agency practices are } \\
\text { consistent with public health laws } \\
\text { and regulations }\end{array}$ \\
\hline $\begin{array}{l}\text { 1.2 } 2^{\mathrm{b}} \text { Identify and apply public health laws } \\
\text { (e.g., statutes, regulations, ordinances, } \\
\text { and court rulings) pertinent to } \\
\text { practitioner's jurisdiction, agency, } \\
\text { program, and profession }\end{array}$ & $\begin{array}{l}\text { Describe public health authority } \\
\text { and the limits on that authority } \\
\text { relevant to the practitioner's } \\
\text { scope of work } \\
\text { Apply basic provisions of the state } \\
\text { and local health code within a } \\
\text { particular area of practice }\end{array}$ & $\begin{array}{l}\text { Describe jurisdictional public health } \\
\text { authority and the limits on that } \\
\text { authority } \\
\text { Apply basic provisions of the state } \\
\text { and local health code within a } \\
\text { particular area of practice }\end{array}$ & $\begin{array}{l}\text { Describe jurisdictional public } \\
\text { health authority and limits on } \\
\text { that authority } \\
\text { Establish public health programs } \\
\text { and agency practices that are } \\
\text { consistent with laws and } \\
\text { regulations } \\
\text { Apply public health authority to } \\
\text { advance public health goals and } \\
\text { improve community health status }\end{array}$ \\
\hline $\begin{array}{l}1.3^{\mathrm{c}} \text { : Describe the protocol for contacting } \\
\text { and best practices for engaging with legal } \\
\text { and/or ethical advisors and other key } \\
\text { public health law resources }\end{array}$ & $\begin{array}{l}\text { Follow protocols for contacting } \\
\text { and engaging with public health } \\
\text { legal counsel and other public } \\
\text { health law resources }\end{array}$ & $\begin{array}{l}\text { Communicate and manage protocols } \\
\text { for contacting and engaging public } \\
\text { health legal counsel and other } \\
\text { public health law resources }\end{array}$ & $\begin{array}{l}\text { Establish and maintain protocols, } \\
\text { in consultation with legal counsel, } \\
\text { for contacting and engaging } \\
\text { public health legal counsel and } \\
\text { other public health law resources }\end{array}$ \\
\hline
\end{tabular}

Note. Training toward this competency might address the following:

a (a) legal framework for U.S. public health practice; (b) constitutional rights implicated through public health practice such as equal protection; (c) federalism, preemption, and police powers; (d) sources of civil versus criminal law exposure in public health practice; (e) federal Indian law principles (sovereignty, trust responsibility, etc.); (f) privacy and confidentiality; (g) local, state, and federal legislative process; (i) rule-making roles and processes.

b (a) major federal, state, and local statutes, case law, regulations, and executive orders; (b) laws and regulations related to public health financing, data collection, sharing, reporting, and anti-lobbying; (c) impact of social, economic, and legislative changes on federal and state health programs; (d) manage and implement programs and practices that are consistent with public health laws and regulations; (e) basic provisions of the governmental unit's health code and regulations within the particular area of practice; (f) evaluation of the impact of law and legal interventions; (g) social determinants of health; (h) social justice/equity; (i) distinction between general and specific public health authority.

c (a) working legally at a local, state, or federal public health agency; (b) preparing for and/or avoiding litigation; (c) articulating public health objectives and framing legal questions. 


\section{Competency Statement}

2.1 a: Describe law-based tools, procedures, and resources available to public health agencies during a declared or undeclared public health emergency

\section{Tier 1}

Entry Level Apply relevant legal information, tools, procedures, and remedies, including injunctions, closing orders, and abatement orders

\section{$2.2^{\mathrm{b}}$ : Identify law-based tools and} enforcement procedures available to address day-to-day (nonemergency) public health issues

2.3c: Recognize the legal authority and limits of critical system partners and others who influence health outcomes
Describe how law and legal practices contribute to the current health status of the population

Apply legal tools and enforcement mechanisms that aim to advance jurisdictional public health goals

Distinguish public health agency powers and responsibilities from those of other governmental agencies, executive offices, police, legislatures, and courts
Tier 2

Supervisory

Manage changes in authority

during a declared emergency

Communicate legal authority and

procedures to emergency response partners

Apply legal tools to address jurisdictional public health goals and program priorities

Manage the application of selected legal interventions and enforcement mechanisms and ensure they are consistent with current science and federal and state laws

Distinguish public health agency powers and responsibilities from those of other governmental agencies, executive offices, police, legislatures, and courts
Tier 3

Executive

Issue, and work with partners to enforce, relevant orders during a public health emergency

Manage emergency preparedness programs that are consistent with relevant federal and state laws and regulations and local ordinances and policies

Implement the use of legal tools to address specific public health goals within the agency's legal authority, jurisdiction, and operational plan

Issue, and work with partners to develop practical and legally sustainable enforcement strategies

Coordinate with the legal authorities of other governmental agencies, executive offices, police, legislatures, and courts

Provide guidance on current and potential political and other influences on public health programs and practice

Note. Training toward this competency might address the following:

a (a) use of injunctions, closing orders, or abatement orders in an emergency; (b) searches, seizures, and destruction of property for public health purposes during a public health emergency; (c) authorities related to the distribution and dispensation of medical supplies during a public health emergency; (d) social distancing, evacuation, quarantine and isolation orders, closure of public places, and curfews; (e) state and federal laws related to preparing for and responding to public health emergencies; (f) changes in legal landscape upon declaration of an emergency.

b (a) direct regulation of persons, professionals, and businesses; (b) how law can be used to alter the informational, socioeconomic, and built environments; (c) the U.S. tort system; (d) pursuing legal and administrative remedies; (e) use of taxing and spending powers to influence public health.

c (a) communicating with legislators; (b) education versus advocacy; (c) urban planning; (d) working with urban planning, transportation, and agricultural systems; (e) the judiciary and public health. 


\section{Appendix C \\ Legal Epidemiology Competency Model}

Table C1. Domain 1: General Legal Epidemiology Competencies

\begin{tabular}{|c|c|c|c|}
\hline Competency Statement & Tier 1 & Tier 2 & Tier 3 \\
\hline $\begin{array}{l}\text { 1: Articulate the importance } \\
\text { of legal epidemiology } \\
\text { concepts to inform health, } \\
\text { fiscal, administrative, legal, } \\
\text { social, and political research } \\
\text { and discourse }\end{array}$ & $\begin{array}{l}\text { 1.1.1a: Conduct background research } \\
\text { on a problem in terms of public health } \\
\text { burden, including burdens, } \\
\text { disparities, and applicable laws and } \\
\text { policies } \\
\text { 1.1.1b: Define and describe basic legal } \\
\text { epidemiology principles and concepts } \\
\text { 1.1.1c: Identify opportunities to include } \\
\text { legal epidemiology principles in } \\
\text { existing organizational activities }\end{array}$ & $\begin{array}{l}\text { 1.1.2a: Identify key sources of data for } \\
\text { legal epidemiology purposes } \\
\text { 1.1.2b: Link legal epidemiology } \\
\text { concepts to existing and planned } \\
\text { public health activities and programs } \\
\text { 1.1.2c: Identify opportunities to } \\
\text { incorporate legal epidemiology } \\
\text { principles in cross-sector } \\
\text { collaborations, funding applications, } \\
\text { and outreach }\end{array}$ & $\begin{array}{l}\text { 1.1.3a: Identify needs for health, fiscal, } \\
\text { administrative, legal, social, and } \\
\text { political research } \\
\text { 1.1.3b: Explain legal epidemiology } \\
\text { concepts to transdisciplinary } \\
\text { collaborations, partnerships, and team } \\
\text { building } \\
\text { 1.1.3c: Promote legal epidemiology } \\
\text { principles and concepts in } \\
\text { organizational strategic planning } \\
\text { processes and in policy agendas for } \\
\text { federal, state, tribal, local, territorial, } \\
\text { and global public health programs, as } \\
\text { well as nongovernmental organizations } \\
\text { and academic programs }\end{array}$ \\
\hline $\begin{array}{l}\text { 2. Apply legal epidemiology } \\
\text { principles to research } \\
\text { studies, funding } \\
\text { opportunities, and policy } \\
\text { agendas }\end{array}$ & $\begin{array}{l}\text { 1.2.1a: Apply basic ethical and legal } \\
\text { principles pertaining to the collection, } \\
\text { maintenance, use, and dissemination } \\
\text { of legal epidemiology data } \\
\text { 1.2.1b: Serve as a member of a } \\
\text { transdisciplinary legal epidemiology } \\
\text { research team } \\
\text { 1.2.1c: Collaborate across relevant } \\
\text { disciplines to effectively use the } \\
\text { resources allocated for specific legal } \\
\text { epidemiology studies } \\
\text { 1.2.1d: Draft study documentation, } \\
\text { including scoping information and } \\
\text { legal epidemiology research protocols, } \\
\text { codebooks, and data sheets }\end{array}$ & $\begin{array}{l}\text { 1.2.2a: Determine study processes and } \\
\text { outcomes (timeline, Institutional } \\
\text { Review Board coordination, } \\
\text { publications) } \\
\text { 1.2.2b: Assemble a transdisciplinary } \\
\text { legal epidemiology research team } \\
\text { across disciplines, including } \\
\text { assignment of roles and } \\
\text { responsibilities } \\
\text { 1.2.2c: Assign available resources to } \\
\text { activities needed to support high } \\
\text { quality legal epidemiology research } \\
\text { 1.2.2d: Recommend study } \\
\text { documentation processes to finalize } \\
\text { coding schemes and research } \\
\text { protocols }\end{array}$ & $\begin{array}{l}\text { 1.2.3a: Ensure relevant approvals are } \\
\text { obtained for research studies } \\
\text { 1.2.3b: Manage a transdisciplinary legal } \\
\text { epidemiology research team } \\
\text { 1.2.3c: Allocate funding for legal } \\
\text { epidemiology studies within new or } \\
\text { existing programs } \\
\text { 1.2.3d: Oversee the completion of study } \\
\text { documentation }\end{array}$ \\
\hline
\end{tabular}

Table continues 


\begin{tabular}{|c|c|c|c|}
\hline Competency Statement & Tier 1 & Tier 2 & Tier 3 \\
\hline $\begin{array}{l}\text { 3. Communicate legal } \\
\text { epidemiology findings, } \\
\text { methodologies, and } \\
\text { recommendations to lay and } \\
\text { professional audiences }\end{array}$ & $\begin{array}{l}\text { 1.3.1a: Contribute to research papers, } \\
\text { articles, reports, or abstracts } \\
\text { 1.3.1b: Create audience-appropriate } \\
\text { oral and visual presentations } \\
\text { 1.3.1c: Communicate legal } \\
\text { epidemiology methods and analyses } \\
\text { for feedback and critique } \\
\text { 1.3.1d: Identify actionable next steps } \\
\text { on the basis of legal epidemiology } \\
\text { findings to advance health outcomes }\end{array}$ & $\begin{array}{l}\text { 1.3.2a: Author research papers, } \\
\text { articles, reports, and abstracts } \\
\text { 1.3.2b: Recommend audience- } \\
\text { appropriate communication methods } \\
\text { for the dissemination of legal } \\
\text { epidemiology materials } \\
\text { 1.3.2c: Identify opportunities to } \\
\text { disseminate methods and processes } \\
\text { for critique } \\
\text { 1.3.2d: Develop recommendations } \\
\text { from research relevant to diverse } \\
\text { audiences }\end{array}$ & $\begin{array}{l}\text { 1.3.3a: Conceptualize a strategy for the } \\
\text { development and dissemination of } \\
\text { written, oral, and graphic materials } \\
\text { 1.3:3b: Participate in peer review of } \\
\text { findings by soliciting and receiving } \\
\text { feedback } \\
\text { 1.3.3c: Partner with stakeholders to } \\
\text { ensure that legal epidemiology findings } \\
\text { are used to inform public health } \\
\text { practice }\end{array}$ \\
\hline $\begin{array}{l}\text { 4. Analyze the use of legal } \\
\text { epidemiology findings to } \\
\text { inform health, fiscal, } \\
\text { administrative, legal, social, } \\
\text { and political activities }\end{array}$ & $\begin{array}{l}\text { 1.4.1a: Document evidence about the } \\
\text { influence of legal epidemiology studies } \\
\text { in informing the ongoing debate on or } \\
\text { reform of related laws or legal } \\
\text { mechanisms }\end{array}$ & $\begin{array}{l}\text { 1.4.2a: Recognize needs for legal } \\
\text { epidemiology studies to inform } \\
\text { ongoing debate and reform of related } \\
\text { laws or legal mechanisms }\end{array}$ & $\begin{array}{l}\text { 1.4.3a: Monitor and evaluate legal } \\
\text { epidemiology findings for their } \\
\text { effectiveness and impact } \\
\text { 1.4.3b: Identify opportunities for } \\
\text { replication, update, and/or expansion of } \\
\text { existing legal epidemiology studies }\end{array}$ \\
\hline
\end{tabular}


Table C2. Domain 2: Competencies for Legal Mapping Studies

\begin{tabular}{|c|c|c|c|}
\hline Competency Statement & Tier 1 & Tier 2 & Tier 3 \\
\hline $\begin{array}{l}\text { 1. Identify opportunities for } \\
\text { legal mapping to inform } \\
\text { the process, nature, and } \\
\text { impact of policies and laws }\end{array}$ & $\begin{array}{l}\text { 2.1.1a: Obtain initial health- and law- } \\
\text { related background information } \\
\text { 2.1.1b: Identify applicable current laws } \\
\text { and policies on an issue } \\
\text { 2.1.1c: Describe the status of the legal } \\
\text { and policy framework surrounding } \\
\text { an issue } \\
\text { 2.1.1d: Draft a problem statement } \\
\text { through background research }\end{array}$ & $\begin{array}{l}\text { 2.1.2a: Select jurisdictions, } \\
\text { populations, or outcomes to analyze } \\
\text { 2.1.2b: Determine data sources with } \\
\text { information needed for analysis } \\
\text { 2.1.2c: Compare the problem to gaps } \\
\text { in current understanding with input } \\
\text { from a subject matter expert } \\
\text { 2.2.1d: Define objectives and scope of } \\
\text { the study }\end{array}$ & $\begin{array}{l}\text { 2.1.3a: Set research priorities such as } \\
\text { topics, types of studies, and outputs } \\
\text { 2.1.3b: Gather input from partners and } \\
\text { activities in the field to finalize a } \\
\text { research question } \\
\text { 2.1.3c: Determine the feasibility of study } \\
\text { objectives }\end{array}$ \\
\hline $\begin{array}{l}\text { 2. Develop policy } \\
\text { surveillance or legal } \\
\text { assessment studies to } \\
\text { address specific research } \\
\text { questions }\end{array}$ & $\begin{array}{l}\text { 2.2.1a: Collect laws or policies } \\
\text { iteratively using online search } \\
\text { platforms on the basis of background } \\
\text { research } \\
\text { 2.2.1b: Generate search string, } \\
\text { variables of interest, definitions, and } \\
\text { coding system on the basis of initial } \\
\text { review of collected information }\end{array}$ & $\begin{array}{l}\text { 2.2.2a: Develop methods and } \\
\text { instruments for collecting valid and } \\
\text { reliable legal or health data } \\
\text { 2.2.2b: Consult with stakeholders, } \\
\text { accrediting bodies, and other } \\
\text { partners regarding legal mapping } \\
\text { standards, measures, and metrics } \\
\text { 2.2.2c: Assign tasks to team members } \\
\text { on the basis of administrative } \\
\text { requirements and resources }\end{array}$ & $\begin{array}{l}\text { 2.2.3a: Confirm the appropriateness of } \\
\text { the legal mapping study scope and } \\
\text { coding system with subject matter } \\
\text { experts } \\
\text { 2.2.3b: Strategize a research agenda } \\
\text { across multiple legal mapping studies }\end{array}$ \\
\hline $\begin{array}{l}\text { 3. Analyze laws, policies, and } \\
\text { political and programmatic } \\
\text { priorities using evidence- } \\
\text { based or empirical } \\
\text { guidelines (including } \\
\text { health-related principles or } \\
\text { trends, stakeholder or } \\
\text { special interests, and other } \\
\text { key developments or } \\
\text { concerns) }\end{array}$ & $\begin{array}{l}\text { 2.3.1a: Apply a coding system to } \\
\text { collected laws and policies using an } \\
\text { iterative process } \\
\text { 2.3.1b: Quantify variations in laws or } \\
\text { policies between jurisdictions or over } \\
\text { time } \\
\text { 2.3.1c: Use relevant databases to track } \\
\text { and assess legal and policy } \\
\text { information }\end{array}$ & $\begin{array}{l}\text { 2.3.2a: Standardize procedures and } \\
\text { systems to ensure quality and } \\
\text { consistency of coding } \\
\text { 2.3.2b: Compare research findings } \\
\text { with study objectives and outcomes } \\
\text { 2.3.2c: Identify opportunities for } \\
\text { innovation and enhancement of } \\
\text { methods or use of new technology or } \\
\text { resources for legal epidemiology } \\
\text { studies }\end{array}$ & $\begin{array}{l}\text { 2.3.3a: Monitor progress and provide } \\
\text { objective feedback on research strategy } \\
\text { using institutional knowledge and } \\
\text { experience } \\
\text { 2.3.3b: Collaborate with partners to } \\
\text { review legal mapping study } \\
\text { methodology, progress, and findings } \\
\text { 2.3.3c: Pursue opportunities for } \\
\text { innovation and enhancement of } \\
\text { methods or use of new technology or } \\
\text { resources }\end{array}$ \\
\hline $\begin{array}{l}\text { 4. Validate and synthesize } \\
\text { results that compare and } \\
\text { contrast meaningful } \\
\text { variations in law and } \\
\text { policy related to health }\end{array}$ & $\begin{array}{l}\text { 2.4.1a: Resolve ambiguities and } \\
\text { discrepancies in legal mapping data } \\
\text { 2.4.1b: Identify trends in legal } \\
\text { mapping } \\
\text { 2.4.1c: Summarize findings from the } \\
\text { legal mapping study }\end{array}$ & $\begin{array}{l}\text { 2.4.2a: Check the validity and } \\
\text { reliability of legal mapping data } \\
\text { 2.4.2b: Confirm research findings and } \\
\text { limitations of legal mapping study } \\
\text { 2.4.2c: Draft conclusions from legal } \\
\text { mapping studies on the basis of the } \\
\text { current legal, public health, and } \\
\text { political context }\end{array}$ & $\begin{array}{l}\text { 2.4.3a: Ensure that the legal mapping } \\
\text { study design, process, and findings } \\
\text { have met the original research } \\
\text { objectives } \\
\text { 2.4.3b: Confirm conclusions in the } \\
\text { context of current knowledge and } \\
\text { information from the field }\end{array}$ \\
\hline
\end{tabular}


Table C3. Domain 3: Competencies for Legal Evaluation Studies

\begin{tabular}{|c|c|c|c|}
\hline Competency Statement & Tier 1 & Tier 2 & Tier 3 \\
\hline $\begin{array}{l}1 \text { Identify opportunities for a } \\
\text { legal evaluation study to } \\
\text { address existing legal, } \\
\text { health, or other issues }\end{array}$ & $\begin{array}{l}\text { 3.1.1a: Identify legal evaluation } \\
\text { needs on the basis of gaps in existing } \\
\text { evidence (literature, legal data, and } \\
\text { other evidence) } \\
\text { 3.1.1b: Identify data sources and } \\
\text { analytical tools relevant to studying } \\
\text { research priorities } \\
\text { 3.1.1c: Determine prerequisites for } \\
\text { study development (e.g., legal } \\
\text { mapping datasets, needs for } \\
\text { particular expertise) }\end{array}$ & $\begin{array}{l}\text { 3.1.2a: Assess the utility of legal } \\
\text { evaluation strategies to address } \\
\text { identified gaps } \\
\text { 3.1.2b: Determine the relevance of } \\
\text { interventional, infrastructural, or } \\
\text { intersectional laws to the identified } \\
\text { research priorities } \\
\text { 3.1.2c: Identify resources in light of } \\
\text { the need and the feasibility of the } \\
\text { research, including extramural } \\
\text { funding and staff and stakeholder } \\
\text { involvement }\end{array}$ & $\begin{array}{l}\text { 3.1.3a: Gather support for legal } \\
\text { evaluation from internal and external } \\
\text { stakeholders in the field } \\
\text { 3.1.3b: Establish research priorities on } \\
\text { the basis of the potential for improving } \\
\text { population health, socioeconomic or } \\
\text { cultural disparities, and the public } \\
\text { health system } \\
\text { 3.1.3c: Obtain and allocate resources } \\
\text { for conducting a legal evaluation }\end{array}$ \\
\hline $\begin{array}{l}\text { 2. Design a legal evaluation } \\
\text { to study potential } \\
\text { associations between law } \\
\text { and health }\end{array}$ & $\begin{array}{l}\text { 3.2.1a: Propose options for a research } \\
\text { plan incorporating legal evaluation } \\
\text { theory } \\
\text { 3.2.1b: Identify legal evaluation } \\
\text { study designs with proximal and } \\
\text { distal impacts of law } \\
\text { 3.2.1c: Follow legal and ethical } \\
\text { principles in designing the study }\end{array}$ & $\begin{array}{l}\text { 3.2.2a: Operationalize key } \\
\text { constructs and concepts in a draft } \\
\text { legal evaluation research plan } \\
\text { 3.2.2b: Develop a logic model } \\
\text { incorporating proposed legal } \\
\text { evaluation study designs to inform } \\
\text { the legal evaluation research plan } \\
\text { 3.2.2c: Secure approvals for the } \\
\text { legal evaluation }\end{array}$ & $\begin{array}{l}\text { 3.2.3a: Finalize the research plan, } \\
\text { including engagement with potentially } \\
\text { underrepresented or underprivileged } \\
\text { populations } \\
\text { 3.2.3b: Finalize a logic model, } \\
\text { incorporating the mechanisms through } \\
\text { which the law can deter, encourage, or } \\
\text { compel health-related behaviors } \\
\text { 3.2.3c: Develop a fiscally sound budget } \\
\text { that will support the activities defined } \\
\text { in the research plan and that is } \\
\text { consistent with financial and ethical } \\
\text { rules }\end{array}$ \\
\hline $\begin{array}{l}\text { 3. Collect and analyze } \\
\text { qualitative and } \\
\text { quantitative study data } \\
\text { using generally accepted } \\
\text { research methodologies }\end{array}$ & $\begin{array}{l}\text { 3.3.1a: Collect data relevant to an } \\
\text { issue and appropriately document } \\
\text { the process } \\
\text { 3.3.1b: Collaborate with team } \\
\text { members to review initial results } \\
\text { 3.3.1c: Ensure validity and reliability } \\
\text { of the data } \\
\text { 3.3.1d: Address principles of } \\
\text { epidemiology and informatics in data } \\
\text { collection and analysis }\end{array}$ & $\begin{array}{l}\text { 3.3.2a: Develop a quality control plan } \\
\text { to standardize analytic codes and } \\
\text { outputs } \\
\text { 3.3.2b: Ensure reliability and } \\
\text { adherence to methodology in the } \\
\text { collection and management of data } \\
\text { 3.3.2c: Apply standardized } \\
\text { population categories or variables to } \\
\text { data analysis }\end{array}$ & $\begin{array}{l}\text { 3.3.3a: Determine deadlines and quality } \\
\text { targets for analyses } \\
\text { 3.3.3b: Monitor the legal evaluation } \\
\text { progress within budget and resource } \\
\text { limitations } \\
\text { 3.3.3c: Analyze research results using } \\
\text { institutional knowledge and experience } \\
\text { on the topic, as well as general } \\
\text { knowledge of legal principles }\end{array}$ \\
\hline
\end{tabular}

Table continues 


\section{Competency Statement}

4. Interpret results, draw conclusions, and formulate key findings toward the improvement of public health

\section{Tier 1}

3.4.1a: Identify key findings and limitations from the data collection and analysis

3.4.1b: Describe patterns or trends in data across sources
Tier 2

3.4.2a: Make recommendations for

the interpretation of data,

including, but not limited to,

authority, credibility, currency, and authenticity

3.4.2b: Interpret point estimates and confidence intervals of measures of central tendency and dispersion, disease or event frequency, and measures of association and impact 


\section{Appendix D \\ The 10 Essential Public Health Services}

\section{The 10 Essential Public Health Services}

\begin{tabular}{|c|c|}
\hline \multirow{2}{*}{ Assessment } & 1. Monitor health status to identify and solve community health problems \\
\hline & 2. Diagnose and investigate health problems and health hazards in the community \\
\hline \multirow{3}{*}{$\begin{array}{c}\text { Policy } \\
\text { Development }\end{array}$} & 3. Inform, educate, and empower people about health issues \\
\hline & 4. Mobilize community partnerships and action to identify and solve health problems \\
\hline & 5. Develop policies and plans that support individual and community health efforts \\
\hline \multirow{5}{*}{ Assurance } & 6. Enforce laws and regulations that protect health and ensure safety \\
\hline & $\begin{array}{l}\text { 7. Link people to needed personal health services and assure the provision of health care } \\
\text { when otherwise unavailable }\end{array}$ \\
\hline & 8. Assure competent public and personal health care workforce \\
\hline & $\begin{array}{l}\text { 9. Evaluate effectiveness, accessibility, and quality of personal and population-based health } \\
\text { services }\end{array}$ \\
\hline & 10. Research new insights and innovative solutions to health problems \\
\hline
\end{tabular}

Note. Source: CDC (2018).

The Journal of Social, Behavioral, and Health Sciences is an open-access, peer-reviewed, online interdisciplinary journal focusing on research findings that address contemporary national and international issues. Its objectives are to (a) encourage dialogue between scholars and practitioners in the social, behavioral, and health sciences that fosters the integration of research with practice; (b) promote innovative models of interdisciplinary collaboration among the social, behavioral, and health sciences that address complex social problems; and (c) inform the relationship between practice and research in the social, behavioral, and health sciences.

Walden University Publishing: http://www.publishing.waldenu.edu 